\title{
Social Networking Sites As Emerging Communication Avenue For Social Influence Via E-Formity: Insights And Future Perspective In Indian Economy
}

\author{
Dr. Arun Kaushal ${ }^{*}$ \\ a*Assistant Professor, Institute of Business Management, GLA University, Mathura, India. \\ E-mail: arun.kaushal@gla.ac.in
}

Article History: Received: 11 January 2021; Accepted: 27 February 2021; Published online: 5 April 2021

\begin{abstract}
In rapid changing technological environment, a number of communication tactics are available for marketers of the 21 st century that involves several new features including mouth- to- mouth promotion that has taken radical step in the form of social media marketing especially via social networking sites (Ceil, 2019).This new form of marketing is also known as Electronic Word -of- mouth communication (e -WOM) and viral marketing (Roy, Datta, \& Mukherjee, 2019). In current paper, an attempt has been made to discuss the hidden insights about significant contributions of social networking sites for social influence in the form of e-formity. In order to proceed for this study, the deep and critical literature review was done by reading the research papers from Jstor, Emerald, Wiley, Taylor and Francis, Science Direct, Elsevier, Google scholar, etc. The information about internet user behavior of top ranked counties will also provide insights and knowledge to researchers or marketing professionals so that online marketing strategies can be cultivated for business organizations accordingly.
\end{abstract}

Keywords: Social Networking Sites, E-Formity, Social Influence, Marketing Communication, Blogs, Discuss Forums.

\section{Introduction}

In the present era of revolutionary and digitized business environment, Marketing Communication has shown its immense importance and the evidence for this is revealed from the growth in advertising expenditure that had that expected rise to 57,486 crores $(15.5 \%)$ in 2016 with digital advertising expanding at the fastest pace of $47 \%$ (Choudhary, Vidhi, 2016). Adaptation of technology and internet of things by business organizations is the significant element for overall development of their business models(Trașcă, Ștefan, Sahlian, Hoinaru, \& ŞerbanOprescu, 2019).The success of marketing in fast changing communication environment depends upon how efficiently companies communicates with its customers (Shukre \& Singh, 2009) in order to inform ,persuade and remind them about the brands and products which it sells (Kotler et al, 2009). For an instance, adaptation of technology can be understood by knowing this information that social media partner Facebook has recently lunched new app like Pinterest called 'Hobbi' which is well accepted in the western part of the world countries like USA, Australia and Canada (2020, www.livemint.com).

In the past, marketing communications and advertising went to work only for the purpose to increase sales, but today advertising is being considered as one of the important elements of customer service(Royo-Vela \& Black, 2020).With the development of communication technology, advertising is creating value for customers (Yoo, Lee, \& Park, 2010). Moreover, the emergence of internet has changed the total scenario of adverting and marketing. It has vastly altered the ways in which people view, use and interact with media and this has in some way changed the effectiveness of traditional marketing techniques while creating new marketing opportunities (Ulin, 2019)). Traditional advertising is all about interruptions and it distrusts the people and draws their attention when they are concentrating on it, like a T.V. program, news papers or magazine articles. People have become so inundated with advertising that they have stated ignoring these messages (YILMAZ, 2019)). As advertiser, communicates the messages to the people without knowing their willingness to receive the messages that interrupts people's activities. Therefore in modern times, consumers are increasing resistant to traditional marketing (Vimali \& Khan, 2018)). While facing these problems, companies are also compelled to think of new ways to communicate with their target audience, which are more effective with regards to budget /brand recognition ratio (Vimali \& Khan, 2018)). In current paper, an attempt has been made to discuss the hidden insights about significant contributions of social networking sites for social influence in the form of e-formity.

In rapid changing technological environment, a number of communication tactics are available for marketers of the $21^{\text {st }}$ century that involves several new features including mouth- to- mouth promotion that has taken radical step in the form of social media marketing especially via social networking sites (Ceil, 2019)). This new form of marketing is also known as Electronic Word -of- mouth communication (e WOM) and viral marketing (Roy, et al., 2019). 


\section{Electronic Word -of- Mouth Communication}

Electronic Word -of- mouth communication is electronically extended version of traditional form of word-of -mouth that takes place online for sharing consumption related information by the customers (Datta et al., 2005; Schiffman, et al., 2011). Some researchers used to express e-WOM in different terms such as online word-ofmouth or internet word-of-mouth (Sun et al., 2006; Godar, 2005; Goyette et al., 2010). Electronic Word -ofmouth communication (e-WOM) refers to "any positive or negative statement made by potential, actual or former customers about products or company, which is made available to a multitude of people and institutions via internet" (Hennig - Thurau et al., 2004). The power of interpersonal influence is further accelerated with introduction of new communication technologies (Cheug and Thadani, 2010).

\subsection{Technologies for Spreading Electronic Word - of- Mouth Communication (E -WOM)}

- Virtual Opinion Platform have emerged as special internet websites that enables the consumers to read the opinions, comments and experiences of other consumers relating to wide of merchandise, services and companies (Hennig - Thurau and Walsh, 2003; Khasmmash, 2008). These are used as spreaders of information about products and services. The web base opinion sites allow posters to make comments on variety of items (Godar, 2005). The famous opinion platform in India is mouthshut.com having 10,000,000 - 100,000,000 registered users (www. Social networking, findthebest.com; Sharma and Kaur, 2014).

- Discussion Forums has thousands of participants from many countries. These forums are web based applications that allow the posting of comments and responses often involving members of virtual community. Moreover, these are more popular with consumers as they seek information and share experiences about products and services (Godar, 2005).

- Blog or Weblog is personal online journals or diaries which are well initiated and managed by bloggers (Godar, 2005; Kotler et al, 2009; Schiffman, et al., 2011). This is the most powerful platform for exchange of consumption related information and also includes comments posted by readers (Schiffman, et al., 2011).

- E-mail is effective communication channel that enables easily transmission of promotional from companies to consumers or from consumers to consumers.

- Social Network or Media Sites benefited marketers and consumers (Gunawan and Huarng, 2015). And since last few years the usage of social network and media sites is growing very quickly (Farooq and Jan,2012; Gunawan and Huarng, 2015). In India, www.facebook.com is one of the famous networking sites which has 112 million Indian users, second largest users base after USA (Farooq and Jan, 2012). Social networking sites are online virtual communities that allow the users to pass along the promotional messages to other persons of similar interests or with whom they have strong relations (Gunawan and Huarng, 2015; Schiffman, et al., 2011).

- Video Sharing Websites are online which enables the users to upload, watch, download and comment on video clips or commercial advertisements (Rune and Vinberg, 2009). The most famous video sharing website is www.youtube.com (Kotler et al., 2009; Schiffman, et al., 2011).

\section{Understanding E-Formity}

One of the biggest factors that may influence the buying behavior is the group to which the individual belongs. In context of e-commerce, it will refer to virtual community that enables an individual to connect and share their views with others, at global level, even if they are not physically meeting with each others. Smartphones have made possible for an individual to connect with their circle of friend, family, colleagues and workmen at anytime and anywhere. This close-up the distance between the two and hence an easy share of information and views regarding a product and services. Based on these information and the belongingness of an individual towards the group will cultivate the concept of consumer conformity. Harris and Rae (2009) concluded that future of the markets and business organizations is solely dependent on the social network channels because they are helpful to make business environment modern as it transform business to be open and collaborative. Akehurst (2009); Huang (2011); Hudson \& Hudson (2013) stated that in the context of restaurant, social media provides platform to not only reach to the n number of consumers but it also influence others to make purchase or buy decisions.

Furthermore, Hays, Page and Buhalis (2013) suggested that social media is on the experimental stage with high percentage of variation in the term of strategy. Therefore, it is required that restaurant area to be vaster that can convert social networking site engagement threw conversation, collaboration and sharing etc. This advanced 
virtual or virtual community is an essential point of discussion for marketers as well. Online (virtual) community of diversified portfolio in context of preferences, tastes etc have the ability to reorganize the personality and prospect of how consumers think, grasp and make judgments while make any purchase decision for products and services. These new ways of communication or interaction by internet, a form of social influence is coined as internet conformity (e-formity).

\section{Research Methodology}

In order to proceed for this study, the deep and critical literature review was done by reading the research papers from Jstor, Emerald, Wiley, Taylor and Francis, Science Direct, Elsevier, Google scholar, etc. Apart from this, latest information related to usage of the internet and adaptation of social networking sites has been explored with the help of various websites which provide relevant, significant and authentic information and acts as reliable source. This methodology facilitates the researchers to draft the roadmap for developing this review paper on Social Networking sites as emerging Communication Avenue for Social Influence via e-formity. Identified statistical information from the e-resources were used to develop the graphical and tabulation representation of relevant data so that meaningful interpretation can be developed for better understanding of addressed topic in this study. This methodology also helps the researchers to identified the significant scenarios related to adoption of social networking sites which surely will used by future researchers in order to understand the emerging insights related to current topic of study.

\section{Role of Internet and Social Networking Websites for E-Formity}

The internet has facilitated customers with new and advanced forms of conforming influences. Now, consumers can easily interrelate or commune on a worldwide level and contribute their thoughts to their views in such a way that earlier it was not feasible. Consumers can interact with others in many dissimilar ways through internet communication. A survey done by Nielsen and Net Ratings (Bausch \& Han,2006) described that social networking web sites system proceed up to $47 \%$ growth level consecutively from year by year. Bausch \& Han (2006) revealed that information about number of users of internet that are normally the frequent users of social networking sites and found that $45 \%$ of the internet users are frequent visitors of SNS. Blogs, on the spot chatting and video calling are the popular modes via which online communities or consumers can share their common point of views, thoughts and interests, and persuade others.

According to a research report of SBI, the e-retail market was around USD 6-billion in 2015(PRESS TRUST OF INDIA, 2015). The internet access through computers, smart phones, 3-G and 4G services have enabled social websites to facilitate their consumer share information and views, hence arises the concept of consumer conformity and virtual community influence. One of the Mr. Narendra Modi's programs "Digital India" for the development of India is also going to contribute a lot in the field of e-commerce activities directly or indirectly. Social websites are emerging as a powerful tool for the consumers to be synchronized with the latest trend in the market, resulting excessive buying behavior too(Evans, 2010).

As it is well known fact that internet facilities are increasing day by day and whole world is getting more ways to interact with each other via web world. In today's world, consumers are communicating and sharing information on a large scale through internet, as earlier it was not possible. Now days, more users are using social networking sites to be in touch with each other, building more trust, more community relationship and for getting more social support. Basically, for keeping up close social ties, social networking sites are widely used. In similar context, Wang \& Chang (2013) explained the relevancy of online platform usage to access information for customers and concluded e-commerce websites users are normally dependent on various online sources for information. Now a day's SNS creates an important avenues on the facilitation of global social interconnections. De Bruyn (2008) stated that social media helps the internet user to not only share or exchange information but it also creates positive as well as negative word-of-mouth (WOM) not only about product restaurant consumption as well which are available via internet.

Techno driven system of various counties motivates the general population to adopt the internet platform for their daily life style. Individuals all over the world are more influenced to use internet for their various activities where they are related to purchasing, entertainment, knowledge seeking etc. Thus usage pattern of the world population changes dramatically. Internet users are the individuals who are the frequent dependent on internet via personal computers, mobiles, laptops etc. In 2017, 46.88\% of the world population was users of internet at least once in month (As per report of e Marketer estimates based on World Internet \& Mobile Users, 2017). 
Further, it is estimated that internet acceptance by individuals will touch halfway landmark till 2019, where $50.6 \%$ of the world level population will be the adopters of internet usage (approx. 3.82 billion population of world). Steadily and consistent growth of internet usage pattern in Figure 5.1, shows that in 2021 the $53.6 \%$ of the world population will be the frequent users. Thus, organizations continuously put their efforts to draft digital marketing strategy in such as way so that effective two way communication between web system and user facilitates to attain competitive edge. Normally, P-O-E-M Framework (Scott, 2013) is one of the acceptable models for execution of digital marketing strategy

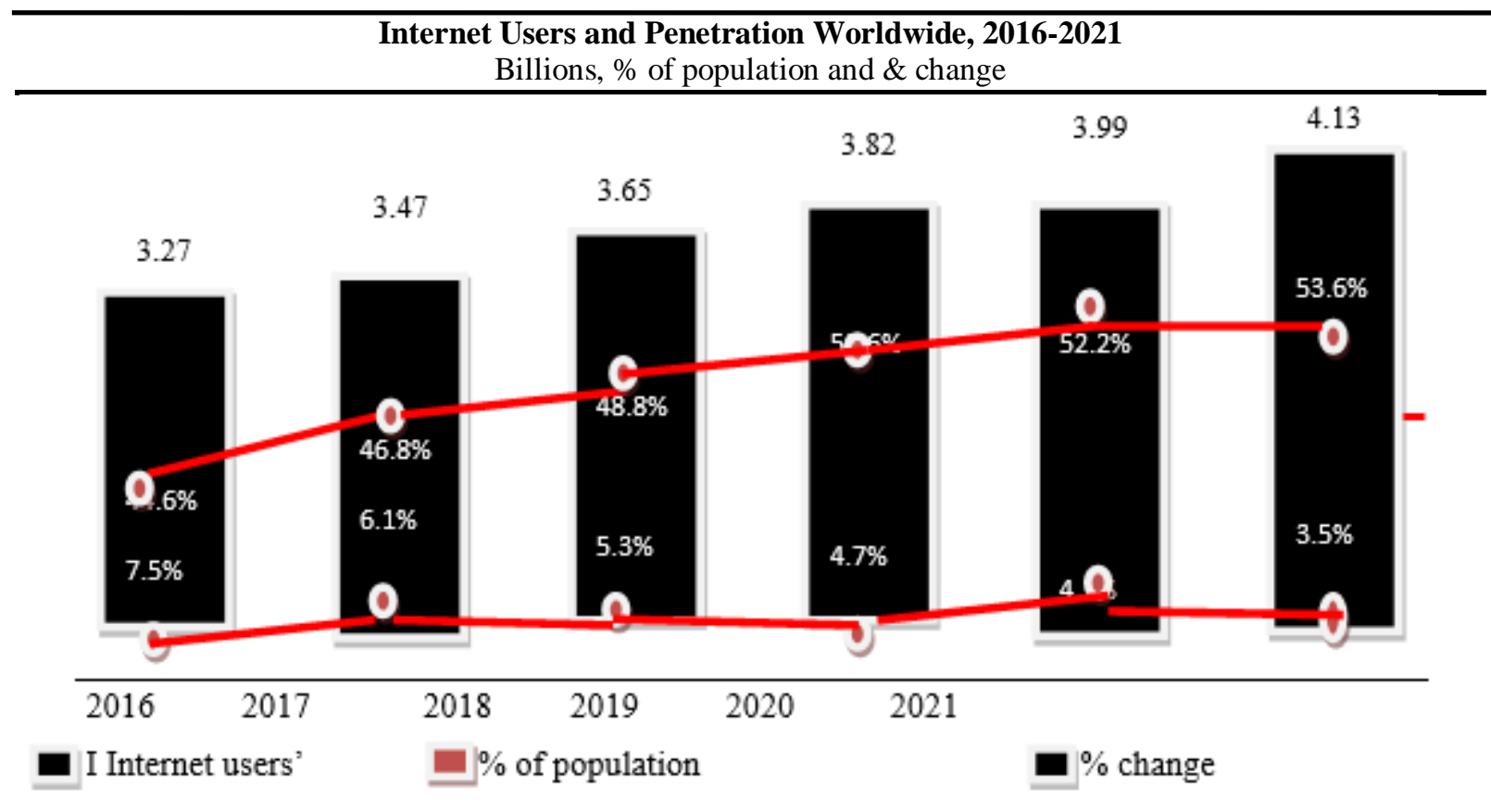

Note: Individuals of any age who use the internet from any location via any device at least once per month. Source: E-Marketer April 2017

Figure 5.1. Internet Users and Penetration Worldwide, 2016-2021

Table 5.1 reveals basic information about internet usage pattern among the individuals country wise.

Table 5.1. Top Ten Countries ranked for internet users (as till December, 2017)

\begin{tabular}{lll}
\hline Rank & Country & $\begin{array}{l}\text { No. of Internet Users } \\
\text { (in Millions ) }\end{array}$ \\
\hline 1 & China & 772 \\
2 & India & 462.12 \\
3 & United States & 312.32 \\
4 & Brazil & 149.06 \\
5 & Indonesia & 143.26 \\
6 & Japan & 118.63 \\
7 & Russia & 109.55 \\
8 & Nigeria & 98.39 \\
9 & Mexico & 85 \\
\hline 10 & Bangladesh & 80.48 \\
\hline
\end{tabular}

Source: www.statista.com

It has been observed from the table 5.1, usage pattern of internet by individuals among various counties progressing at very fast extent. Although United States is one of the developed economies of world but as per the above mentioned data, it can be easily depicted that developing counties like India, China are leading in utility of internet by people of these counties which shows the acceptance of web technology by population of these counties. As of 2017, China is at leading position having (772 million internet users out of 1.38 billion 
populations) because of its ongoing and rapid economic development and cultural orientation towards technology followed by neighbor country of china i.e. India having (462 million internet users) and United States are one third ranks having (312.32 million internet users). Additionally, one another fact noticed from the above data project that overall, all BRIC economies had more than one hundred online internet friendly individuals, accounting for 4 of the 7 economies with more than hundred million online internet users.

As in present study, researchers strives to understand the consumer conformity with the help of social networking sites, hence basic information about usage pattern of social networking sites by individuals needs to be explored. For same, usage pattern of various social networking sites by individuals worldwide is presented in table 5.2

Table 5.2

Most famous social network sites worldwide as of April 2018

\begin{tabular}{lll}
\hline S.No /Rank & Social Network Sites & No. of Active Users (in millions) \\
\hline 1 & Facebook & 2234 \\
2 & Youtube & 1500 \\
3 & Whatsapp & 1500 \\
4 & Facebook Mesenger & 1300 \\
5 & WeChat & 980 \\
6 & Instagram & 813 \\
7 & Tumblr & 794 \\
8 & QQ & 783 \\
9 & Q Zone & 563 \\
10 & Sina Weibo & 392 \\
11 & Reddit & 330 \\
12 & Twitter & 330 \\
13 & Baida Tieba & 300 \\
14 & Skype & 300 \\
15 & Linkedin & 260 \\
16 & Viber & 260 \\
17 & Snapchat & 255 \\
18 & LINE & 203 \\
19 & Pinterest & 200 \\
\hline 20 & Telegram & 200 \\
\hline
\end{tabular}

Source: www.statista.com

From table 5.2, it has been noticed that facebook having (2234 million active users) attained the first rank followed by youtube and whatsapp having (1500 million active users) each till April 2018. From the above mentioned data. It is clear that acceptability of users towards social networking sites increases day by day at international level. It means people have adopted the new technology for their daily life in very positive manner for their social construction with the help of virtual communities.

\section{Internet usage behavior among Indian population}

Internet as well as social networking sites user base has been consistently increasing as depicted in table 1.4 and 1.5 respectively. In 2015, numbers of internet users in India were 315 million depicting 25\% of the overall population of country. Further it was in progression stage as in 2016 and 2017, number of internet users were $373 \& 429$ millions, again representing $30 \%$ \& 34\% of the whole population of Indian demography. Table 6.1 also reveals the fact about future projections about the users of internet in next coming years which finally portraits the uplifting scenario. 
Table 6.1. Internet Usage Pattern in India

\begin{tabular}{lll}
\hline Year & Number of Internet users in India(in millions) & $\begin{array}{c}\text { Internet Users }(\%) \\
\text { of Population }\end{array}$ \\
\hline 2015 & 315 & 25 \\
2016 & 373 & 30 \\
2017 & 429 & 34 \\
2018 & 479 & 37 \\
2019 & 492 (Projected) & 40 (Projected) \\
2020 & 518 (Projected) & 42 (Projected) \\
2021 & 534 (Projected) & 45 (Projected) \\
\hline 2022 & 548 (Projected) & 47 (Projected) \\
\hline
\end{tabular}

Source: www.statista.com

As the internet friendly individuals when engaged in online activities, it has been observed that social networking are at top position. Table 6.1 reveals the information about usage pattern of the Indian population from 2015 to 2022. In 2015, 2016 \& 2017, the numbers of social networking sites users in India were 142 million, 168 million and 196 million respectively, representing 13\%, 15\% and 17\% of the overall population of country. The main reasons for excellent usage by Indian people can be penetration of smart phones usage, easily and cheap availability of internet data by mobile networking companies.

Table 6.2. SNS Usage Pattern in India

\begin{tabular}{ccc}
\hline Year & $\begin{array}{c}\text { Number of social network users in India } \\
\text { (in millions) }\end{array}$ & $\begin{array}{c}\text { SNS Users (\%) of } \\
\text { Population }\end{array}$ \\
\hline 2015 & 142 & 13 \\
2016 & 168 & 15 \\
2017 & 196 & 17 \\
2018 & 226 (Projected) & 19 \\
2019 & 258 (Projected) & 21 \\
2020 & 292 (Projected) & 24 \\
2021 & 336 (Projected) & 27 \\
\hline 2022 & 370 (Projected) & 29 \\
\hline
\end{tabular}

Source: $w$ ww.statista.com

The abovementioned explanation reveals that in India

1. Awareness and acceptability of online techno driven mechanism

2. Popularity among Indians for E-commerce.

3. Progressive trends of Internet usage pattern

4. Up gradation in computer literacy.

5. Acceptability of Indian Population for Social Networking sites

Therefore, kind of growth in online industry fertile soil for healthy adaptation of internet services by business organizations in India. In coming years, this techno driven system has made the customers demanding with anytime and anywhere accesses for their online related activities. So companies have no any other option but to execute online services in their business models.

\section{Discussion and Conclusion}

Digitalization and modernization of various economies like India social networking sites are being used by individuals for exploring information and they are considered as emerging sources for social Influence for final purchase decision. Various virtual social linkage activities like commenting, tagging and sharing information, views and experiences are being adopted by the social networking users. These websites facilitates to the users not only to assess and give opinions to their close reference group members like family, friends and professional friends but also provide opportunity to other people also to share information about products or services used by them (Curras-Perez et al, 2013). Roggeveen \& Coulter (2012) stated that Facebook as social networking platform helps the companies or firms to create their own business (product) pages and further this provide clues to websites users to follow these product pages. These provisions by social networking sites give options to them to receive or disseminate product related information. The information about internet user behavior of top ranked 
counties will also provide insights and knowledge to researchers or marketing professionals so that online marketing strategies can be cultivated for business organizations.

\section{References}

1. Bickart, B., \& Schindler, R.M. (2001). Internet forums as influential sources of consumer information. Journal of interactive marketing, 15(3), 31-52.

2. Briggs, P., Burford, B., De Angeli, A., \& Lynch, P. (2002). Trust in online advice. Social science computer review, 20(3), 321-332.

3. Boush, D.M., Friestad, M., \& Rose, G.M. (1994). Adolescent skepticism toward TV advertising and knowledge of advertiser tactics. Journal of consumer research, 21(1), 165-175.

4. Bausch, S., \& Han, L. (2006). Social networking sites grow 47 percent, year over year, reaching 45 percent of web users, according to Nielsen/Netratings, NetRatings, New York, NY, 18.

5. Bharucha, N. (2015). Online shopping on a rise in India: survey. Retrieved from Times of India: m.timesofindia.com/city/mumbai/Online-shopping-on-a-rise-in-India-survey/articleshow/47897824.cms

6. Ceil, C. (2019). Social Media effects on Emirates Airline. Available at SSRN 3521092.

7. Casalo, L.V., Flavia'n, C., \& Guinalı'u, M. (2008). Fundaments of trust management in the development of virtual communities. Management Research News, 324-338.

8. Cummins, S., Peltier, J.W., Schibrowsky, J.A., \& Nill, A. (2014). Consumer behavior in the online context. Journal of Research in Interactive Marketing, 169-02.

9. Evans, D. (2010). Social media marketing: An hour a day: John Wiley \& Sons.

10. Hennig-Thurau, T., \& Walsh, G. (2004). Electronic word-of-mouth: motives for and consequences of reading customer articulations on the internet, International Journal of Electronic Commerce, 8(2), 5174.

11. Inside Research (2007). Inside the market research industry report, Market Research.com, www.Marketresearch.com

12. Kim, W.G., Lee, C., \& Hiemstra, S.J. (2004), Effects of an online virtual community on customer loyalty and travel product purchases, Tourism Management, 25(2), 343-55.

13. Kozinets, R.V. (1999). E-tribalized marketing? The strategic implications of virtual communities of consumption, European Management Journal, 17(3), 252-264.

14. Park, J., \& Feinberg, R. (2010). E-formity: consumer conformity behaviour in virtual communities. Journal of Research in Interactive Marketing, 197-213.

15. Press Trust of India. (2015). E-commerce SBI.

16. Roy, G., Datta, B., \& Mukherjee, S. (2019). Role of electronic word-of-mouth content and valence in influencing online purchase behavior. Journal of Marketing Communications, 25(6), 661-684.

17. Royo-Vela, M., \& Black, M. (2020). Drone images versus terrain images in advertisements: Images' verticality effects and the mediating role of mental simulation on attitude towards the advertisement. Journal of Marketing Communications, 26(1), 21-39.

18. Shukre, A., \& Singh, V.P. (2009). A study on factors affecting consumer buying behavior in apparel category in delhi and ncr region with special reference to koutons \& cotton county retail stores. National Journal of System and Information Technology, 2(1), 102.

19. Trașcă, D.L., Ștefan, G.M., Sahlian, D.N., Hoinaru, R., \& Șerban-Oprescu, G.L. (2019). Digitalization and Business Activity. The Struggle to Catch Up in CEE Countries. Sustainability, 11(8), 2204.

20. Ulin, J.C. (2019). The business of media distribution: Monetizing film, TV, and video content in an online world: Routledge.

21. Vimali, S., \& Khan, M.K.A. (2018). Impact of Digital Marketing on Consumers Purchase. Journal of Management, 6(S1), 51-55.

22. ILMAZ, R.A.E.S. (2019). The effect of the comments about the hotels on tripadvisor, which is an improved web site, on consumer behavior: Istanbul Case.

23. Yoo, W.S., Lee, Y., \& Park, J. (2010). The role of interactivity in e-tailing: Creating value and increasing satisfaction. Journal of retailing and consumer services, 17(2), 89-96. 